\title{
Investigating the Effect of Magnetic Field on Cortisol, Blood Sugar, Triiodothyronine and Thyroxin Hormones in Rat
}

\section{Naghi Jabbari Vesal (PhD) ${ }^{1}$, Nima Rostampour $(\mathbf{P h D})^{2}$, Roghaie Abbasali Pourkabir $(\mathbf{P h D})^{3}$, Safoora Nikzad $(\mathrm{PhD})^{1, *}$}

${ }^{I}$ Department of Medical Physics, Faculty of Medicine, Hamadan University of Medical Sciences, Hamadan, Iran

${ }^{2}$ Department of Medical Physics, Faculty of Medicine, Kermanshah University of Medical Sciences, Kermanshah, Iran

${ }^{3}$ Department Of Biochemistry, Faculty of Medicine, Hamadan University of Medical Sciences, Hamadan, Iran

* Corresponding Author: Safoora Nikzad, Department of Medical Physics, Faculty of Medicine, Hamadan University of Medical Sciences, Hamadan, Iran.Email: s.nikzad@umsha.ac.ir

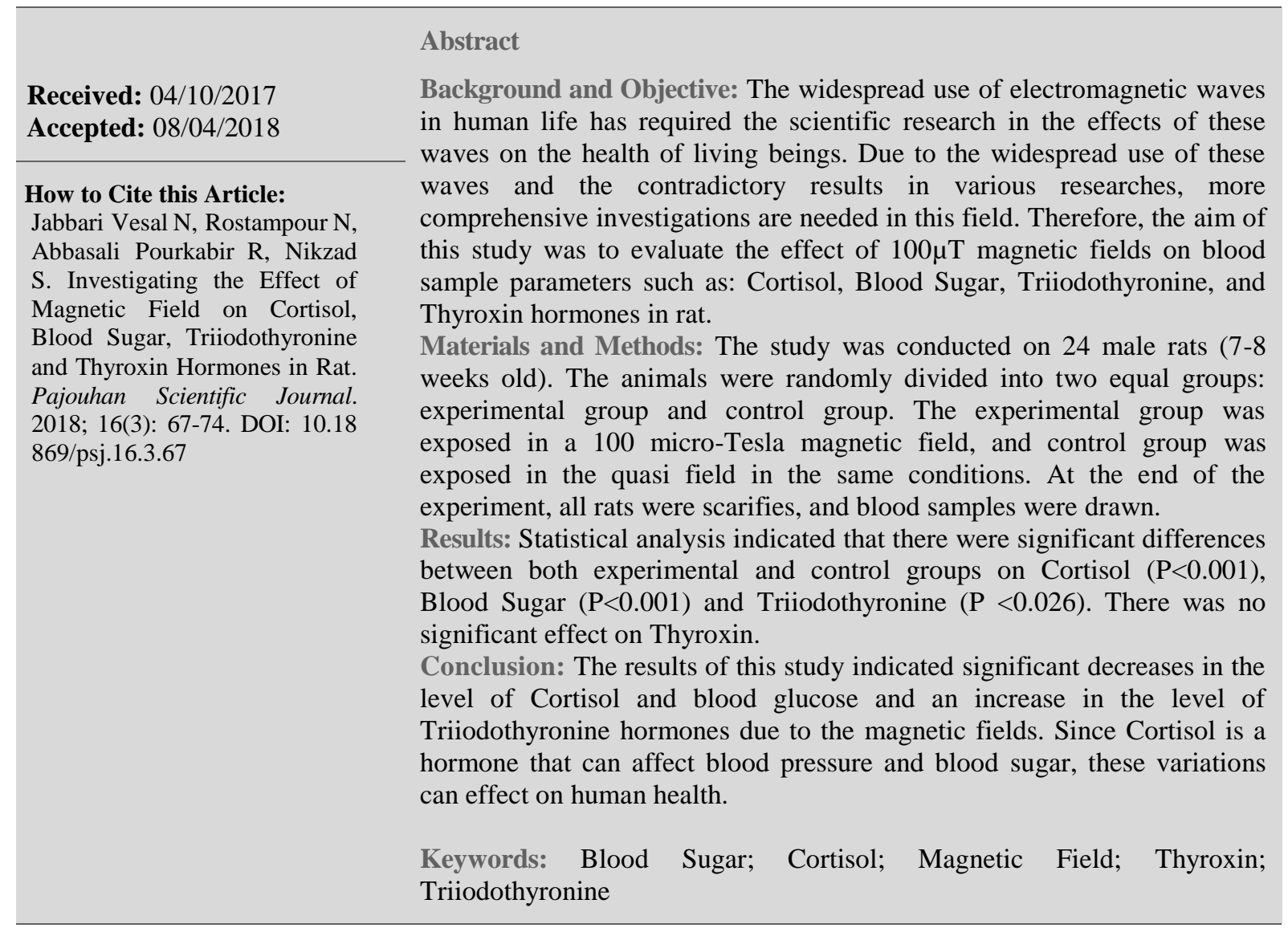


do: $10.18869 / \mathrm{psj} .16 .3 .67$

\title{
بررسى اثر ميدان مغناطيسى بر كورتيزول، قند خون، هورمونهاى ترى يدوتيرونين و تيروكسين موش صحرايى
}

\author{
نقى جبارى وصال'، نيما رستم يور '، رقيه عباسعلى يور كبير "، صفورا نيكزاداء" \\ ' أروه فيزيك يزشكى، دانشكده يزشكى، دانشخاه علوم يزشكى همدان، همدان، ايران

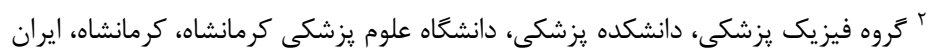

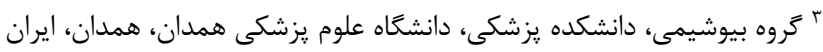 \\ * نويسنده مسئول: صفورا نيكزاد، كروه فيزيك يزشكى، دانشكده يزشكى، دانشعاه علوم يزشكى همدان، همدان، ايران. \\ ايميل: s.nikzad@umsha.ac.ir
}

\begin{tabular}{|c|c|}
\hline קكيده & \\
\hline سابقه و هدف: استفاده وسيع از امواج الكترومغناطيس در زندگى بشر، اهميت تحقيقات علمى در رابطه با & 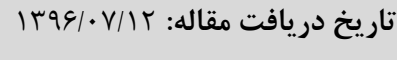 \\
\hline اثرات اين امواج بر سلامت موجودات زنده را ضرورى نموده است. به علت كستركى دامنه استفاده از اين & 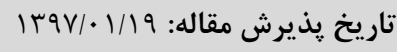 \\
\hline امواج و نتايج ضد و نقيض ارائه شده در مطالعات مختلف، نياز به بررسىهاى جامعتر در اين زمينه ضرورى & \\
\hline 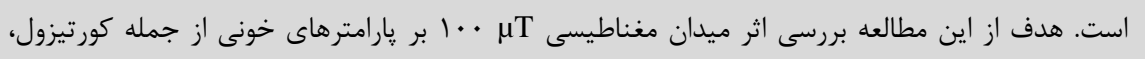 & لمامى حقوق نشر براى دانشخاه علوم \\
\hline قند خون، هورمون هاى ترى يدوتيرونين و تيروكسين موش صحر ايى بود. & \\
\hline مواد و روشها: مطالعه بر روى YF موش صحرايى نر (با سن N- هفته) انجام شد. حيوانات به صورت & \\
\hline تصادفى در دو كروه مساوى آزمون و شاهد تقسيمبندى شدند. كروه آزمون با ميدان مغناطيسى ..1 & \\
\hline ميكروتسلا مورد تابش قرار كرفتند در حاليكه كروه شاهد در ميدان بدون تابش ولى با شرايط مشابه قرار & \\
\hline كَرفتند. در پايان آزمون نمونه هاى خونى موشها جمع آورى شد. & \\
\hline يافته ها: نتايج حاصل نشان داد كه اختلاف معنادارى در مقدار كورتيزول (1 (P</. P)، مقدار قند خون & \\
\hline 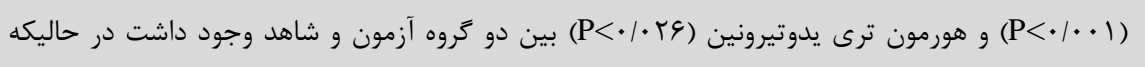 & \\
\hline اثر معنادارى بر روى ميزان هورمون تيروكسين مشاهده نشد. & \\
\hline نتيجهَيرى: نتايج حاصل از اين مطالعه دلالت بر كاهش سطح كورتيزول و قند خون و افزايش هورمون & \\
\hline يدوتيرونين ناشى از اعمال ميدان مغناطيسى داشت. با توجه به اينكه كورتيزول هورمونى است كه مى تواند & \\
\hline بر فشار و قند خون اثر كذارد، اين ميدان ها مى توانند بر سلامتى اثركذار باشند. & \\
\hline وازًٔان كليدى: تيروكسين؛ ترى يدوتيرونين؛ قند خون؛ كورتيزول؛ ميدان مغناطيسى & \\
\hline
\end{tabular}

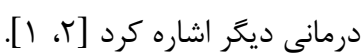

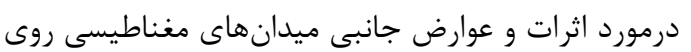

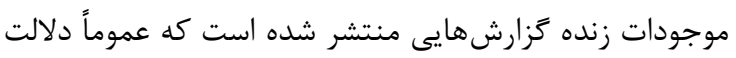

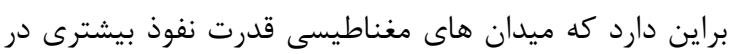

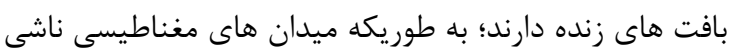

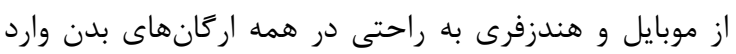

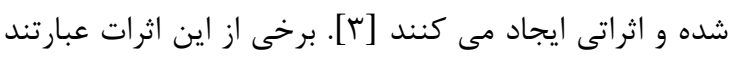

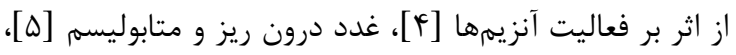

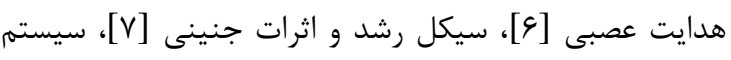

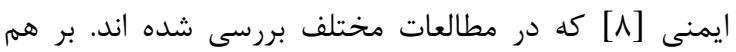

با گسترش روزافزون استفاده از دستكاهها و تجهيزات

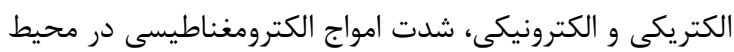

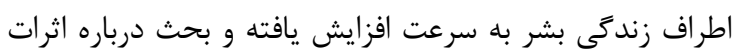

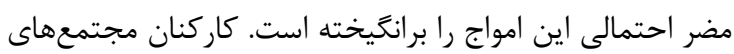

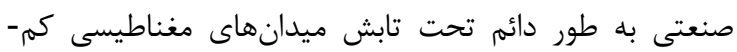

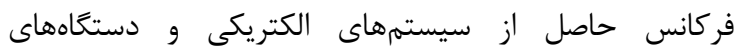

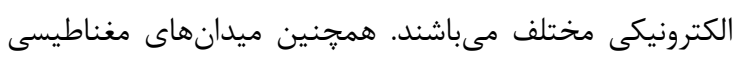
در علوم مختلف يزشكى كاربردهاى فراوانى دارند. از جمله

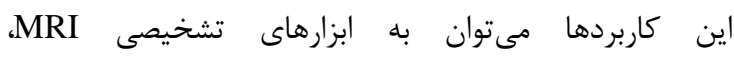

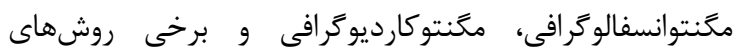


دقيق و كاملى در اين زمينه بهدست نيامده است كه اين مىتواند

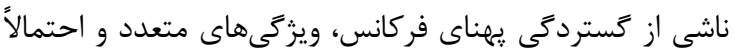

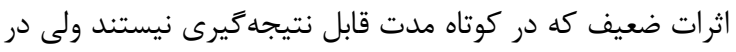

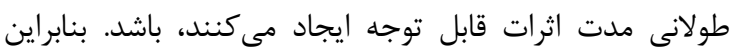

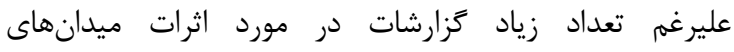

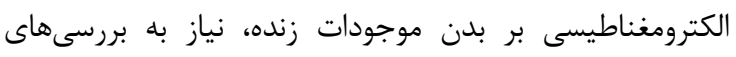

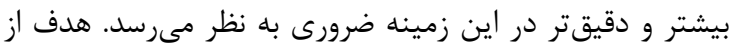

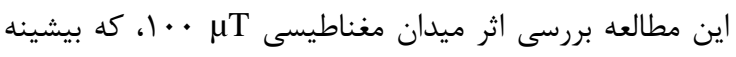

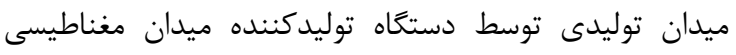

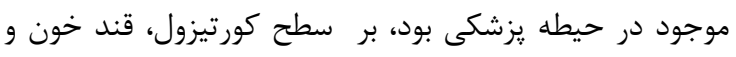

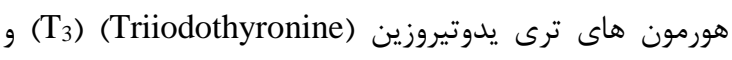

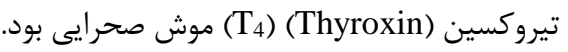

\section{مواد و موشها تهيه حيوانات}

در اين مطالعه FF موش صحرايى نر هم نزاد، با سن حدود

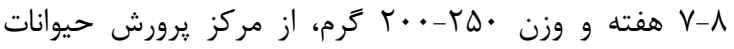

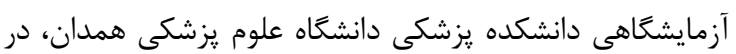

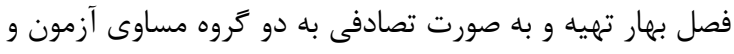

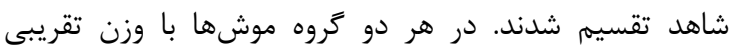

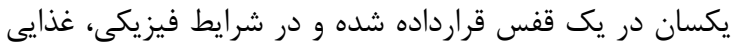

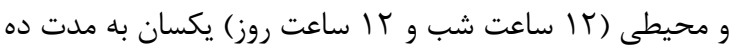

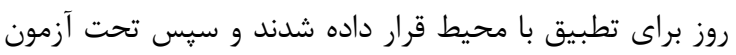

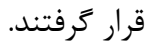

\section{ميدان مغناطيسى و تابش دهى}

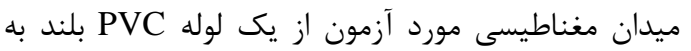

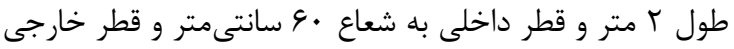

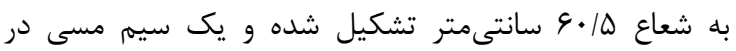
محيط خارجى لوله PVC ييجيده شد. با استفاده از برق شهر و

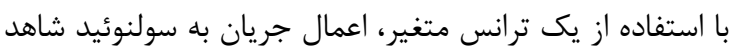

شد (شكل (1).

براى اعمال ميدان مغناطيسى يكنواخت موشها در مركز

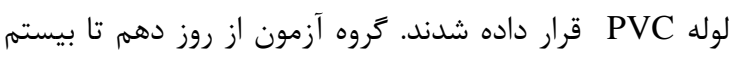

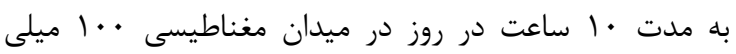

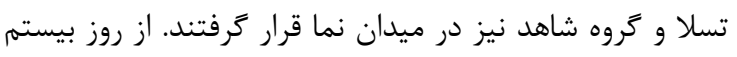

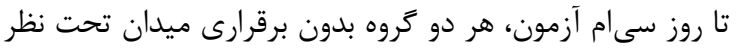

كنش ميدانهاى الكترومغناطيسى با سيستمهاى زنده موضوع مطالعات بسيارى در سطح دنيا بوده است. همجنين مطاطين مطالعات

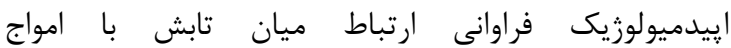

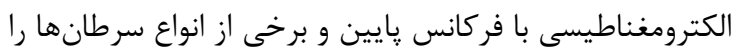

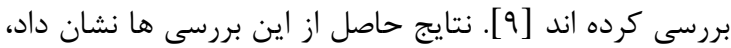

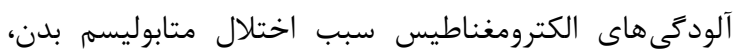

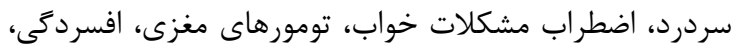

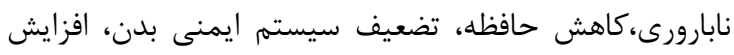

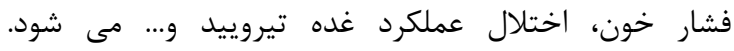

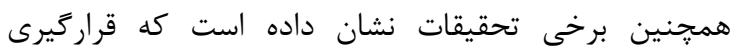

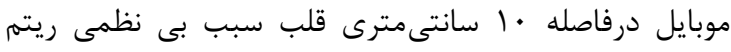

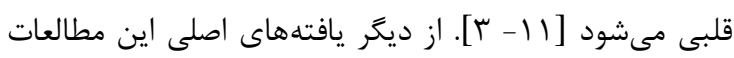

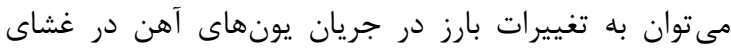

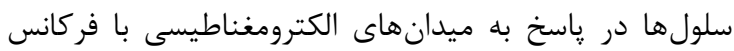

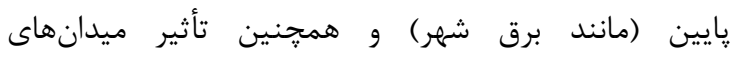
مغناطيسى حاصل بر توليد ملاتونين و فعاليت آنزيمهاى

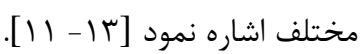
در برخى مقالات منتشر شده مشاهداتى مبنى بر تأثير

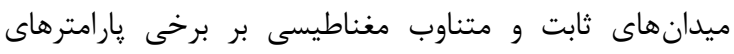

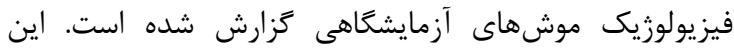
مطالعات اختلالات قابل توجه در متابوليسم كربوهيدرات، ليييد

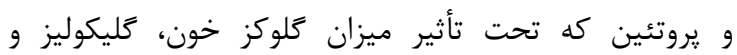

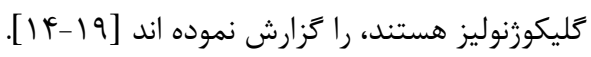

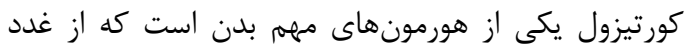
فوق كليوى ترشح مىشود و در مواقعى كه بدن تحت تأثير استرس باشد، ميزان آن تغيير مى كند. كورتيزول باعث بـان بالارفتن

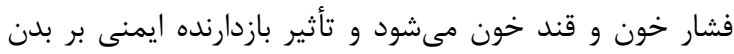

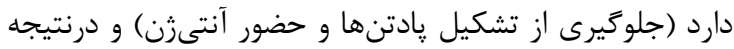

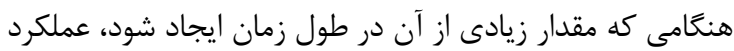

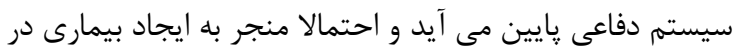

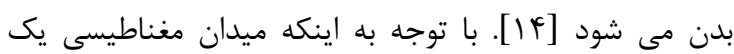

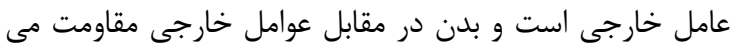

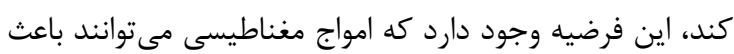
ايجاد استرس شده و بر سطح ترشح كورتيزول اثر بحذارند.

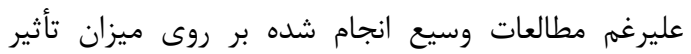

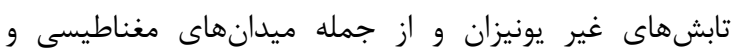

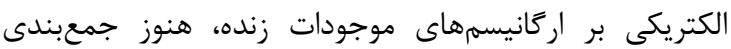

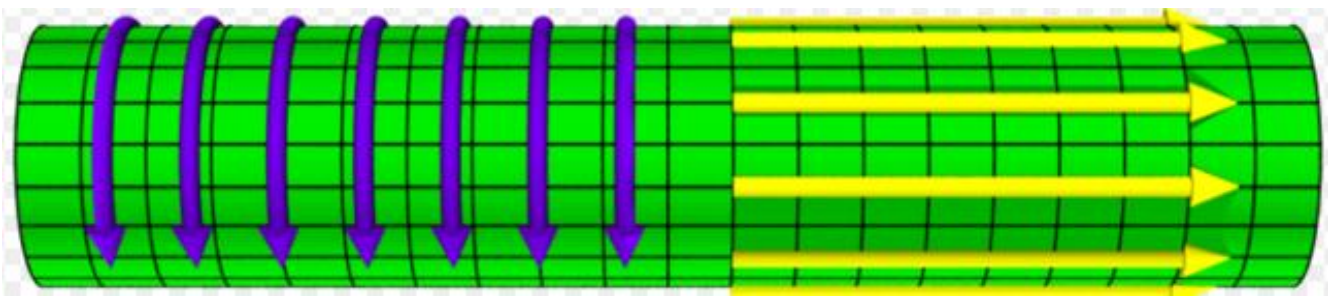

شكل ا: نحوه بِيجيدن سيم بِيج و جهت ايجاد ميدان مغناطيسى در يك لوله سيم بِيج شده 
داده ها براى هر دو گروه آزمون (كروه ()) و گروه شاهد (َروه r) از آزمون Nonparametric Tests SPSS One-Sample Kolmogrov-Smirnov با استفاده از آزمون Independent T-Test آناليز آمارى بين دو گروه آزمون و شاهد براى ساير فاكتورهاى اندازه آدير كيرى

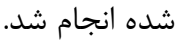

\section{نافته ها}

بعد از جمعآورى دادهها از زروه شاهد و آزمون، جهت

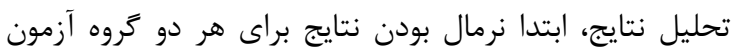

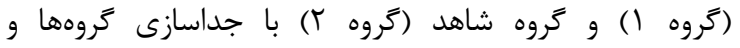

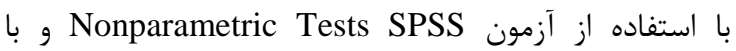
انتخاب One-Sample Kolmogrov-Smirnov بررسى شد أزد

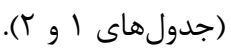
Asymp.Sig نتايج حاصل از اين جدولها نشان مي إنهد (2 tailed) كروههاى ا و r مى باشند. سيس با استفاده از آزمون Independent T-Test آناليز آمارى بين دو كروه آزمون و شاهد براى سنجش فاكتورهاى آزئي

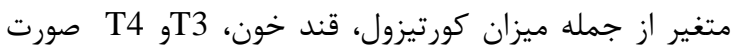

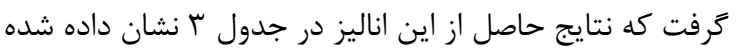

از اثرات مختلف ميدان مغناطيسى روى هر دو گروه را مى توان در تغييرات كورتيزول با مقدار ميانكين

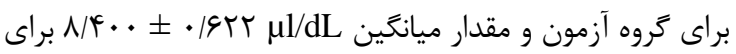

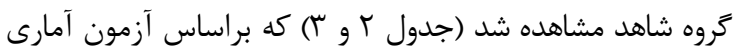

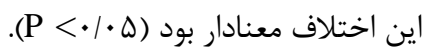

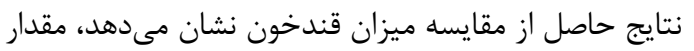

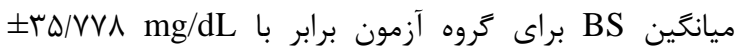

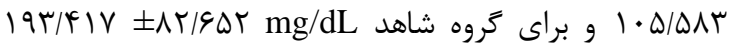

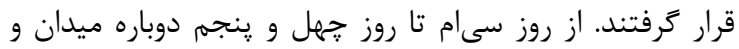

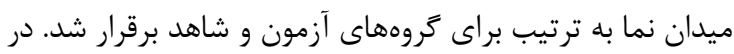

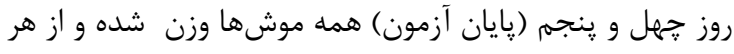

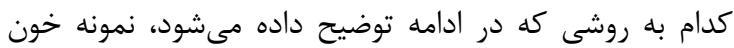
كرفته شد.

\section{تهيه نمونهها و بإرامترهاى خونى}

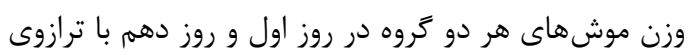

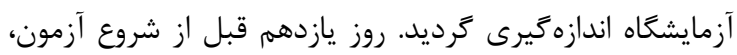
به روش بيهوش نمودن يك نمونه خون از قلب موشها (هر دو

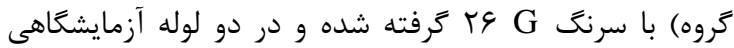

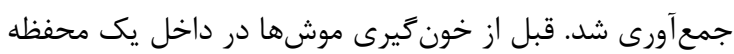

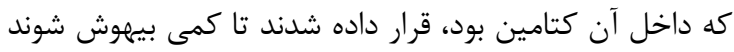

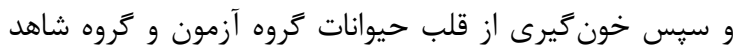

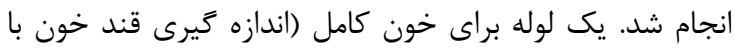

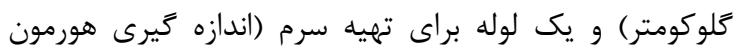

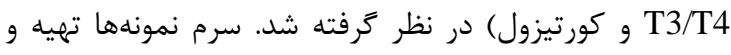

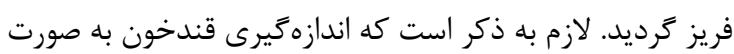

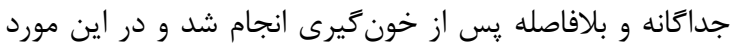

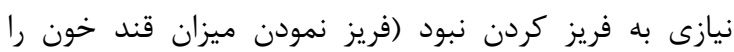

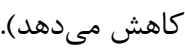
قندخون كامل نمونهها توسط كلوكومتر اندازهكيرى شد. با توجه به تأثير هورمون كورتيزول و هورمونهاى تيروييدى بر برن

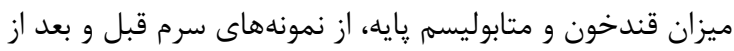
آزمون (روز صفر و روز استفاده شد.

\section{تجزيه و تحليل دادهها}

تجزيه و تحليل آمارى دادهاى بهدست آمدهد بادها استفاده از نرم افزار SPSS (version 16.0.) انجام شد. براى دهديل تحليل

\begin{tabular}{|c|c|c|c|c|}
\hline & $\mathrm{T} 4$ & T3 & & $\mathbf{N}$ \\
\hline Ir & ir & ir & Ir & $\mathbf{N}$ \\
\hline $\begin{array}{l}1 / \cdot \Delta \Delta \wedge E Y \\
r / \Delta \vee \vee \wedge E 1\end{array}$ & $\begin{array}{l}r / \Lambda Q \cdot \cdot \\
1 / \Delta \cdot r F T\end{array}$ & $\begin{array}{l}. / 9 T \Delta A \\
. / 1 T V T F\end{array}$ & $\begin{array}{l}F / T V \Delta . \\
I / T I V \Lambda .\end{array}$ & 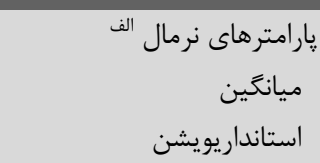 \\
\hline $\begin{array}{l}\cdot / 181 \\
-\cdot / 181 \\
-\cdot 11 \cdot 1\end{array}$ & $\begin{array}{l}\cdot / r q 4 \\
-\cdot / 19 V \\
-\cdot / r q 4\end{array}$ & $\begin{array}{l}\cdot / 14 . \\
-\cdot / 14 . \\
. / .94\end{array}$ & $\begin{array}{c}\cdot / 1 r V \\
-\cdot / 114 \\
-\cdot / 1 r v\end{array}$ & مثيشترين حد تغييرات \\
\hline $\begin{array}{l}.|09| \\
. \mid 1 \mathrm{VQ}\end{array}$ & $\begin{array}{l}1 / \cdot 1 V \\
. / T \Delta Y\end{array}$ & $\begin{array}{l}\cdot / 4 \wedge 9 \\
. / 9 \vee T\end{array}$ & $\begin{array}{l}. / F V F \\
. / 9 V A\end{array}$ & $\begin{array}{r}\text { Kolmogorov-Smirnov Z } \\
\text { Asymp. S.(2-tailed) }\end{array}$ \\
\hline
\end{tabular}

Test distribution is Normal.

. 
جدول r: نتايج حاصل از تست Kolmogorov_Smirov براى ارزيابى نرمال بودن گروه شاهد

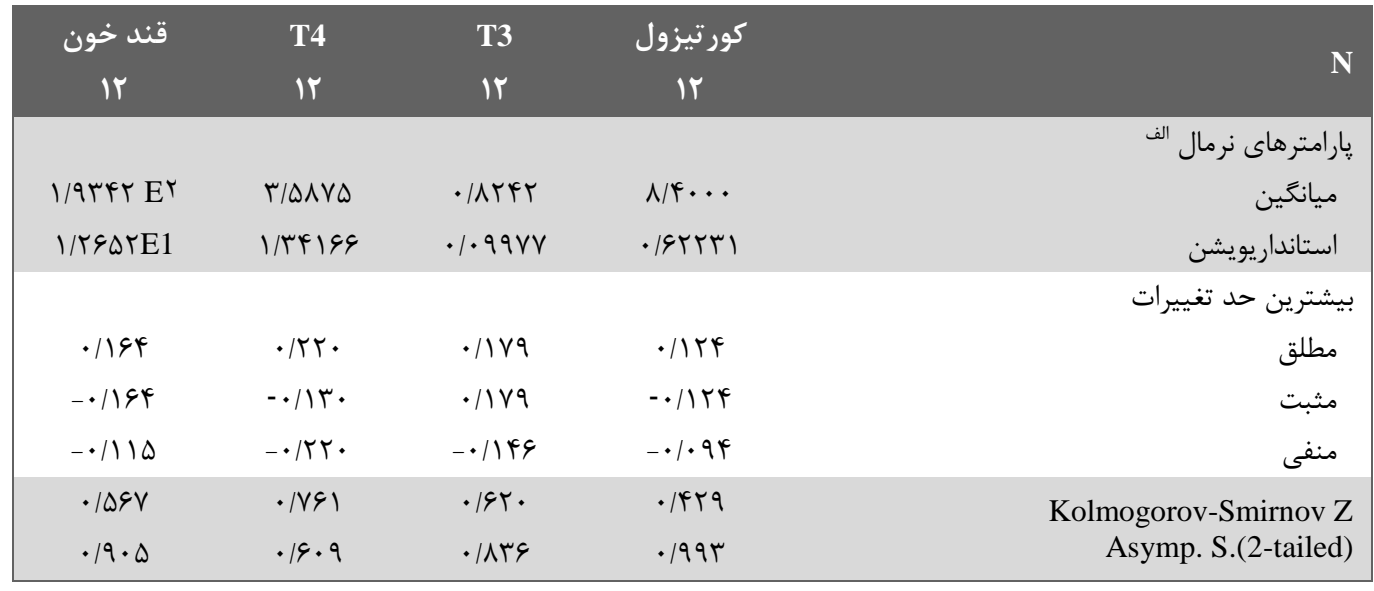

. Test distribution is Normal.

. $.0 r / .$.

جدول بّ: نتايج آمارى براى كروه آزمون وكروه شاهد براى سنجش فاكتورهاى متغير از جمله ميزان كورتيزول، قند خون، T3 و T4

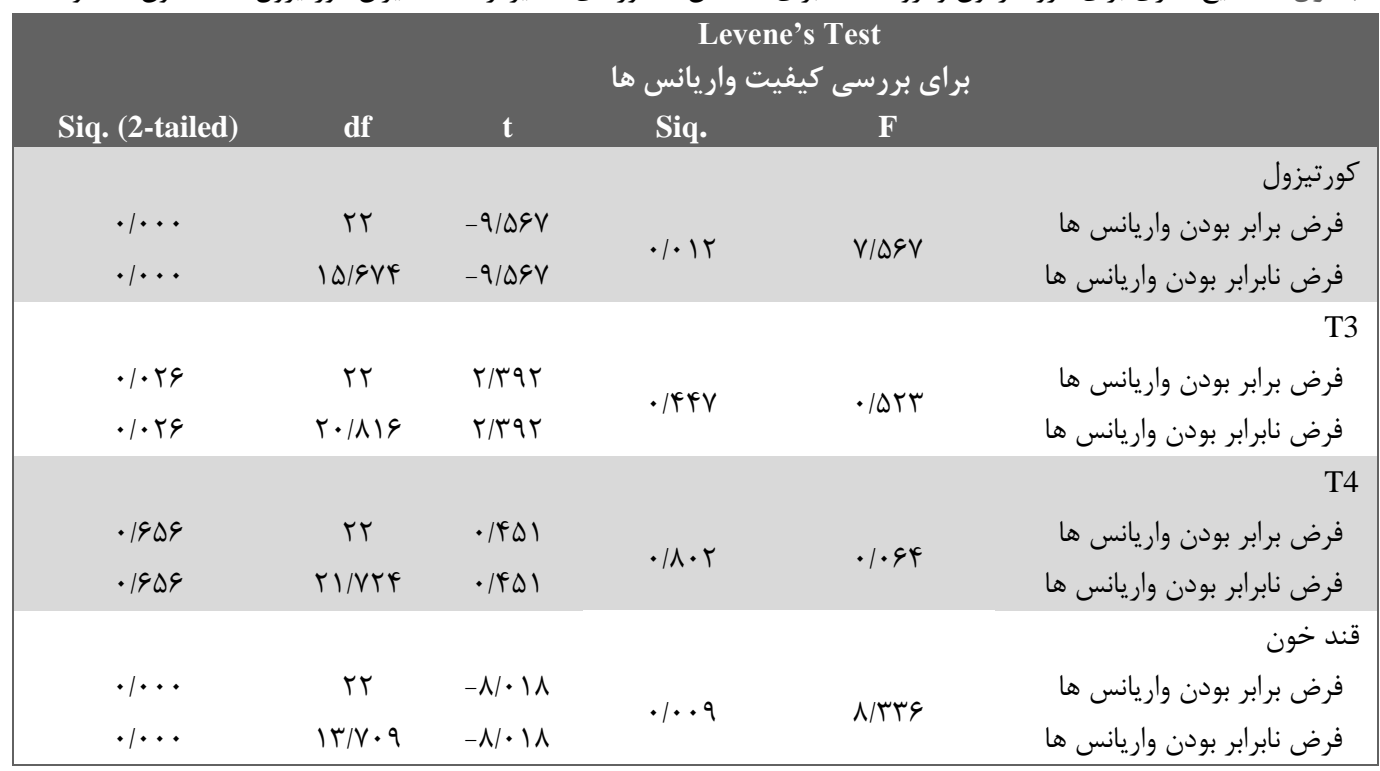

است. ماهيت فيزيكى ميدان هاى الكتريكى براساس قانون كولن

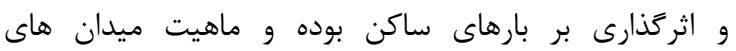

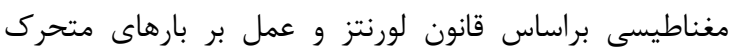

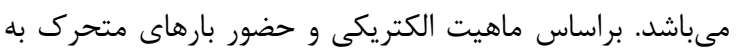

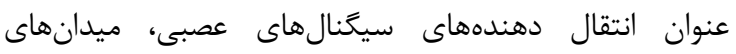

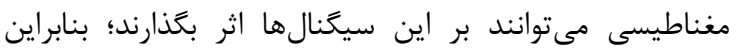

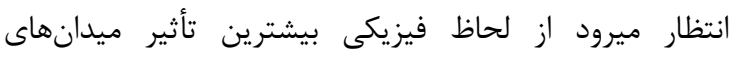

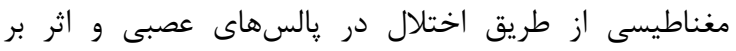

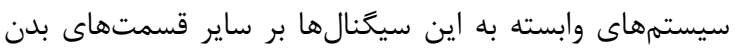
نمايان شود [10]. كورتيزول يكى از هورمونهاى مههم بدن است كه از غدا فدد فوق كليه ترشح شده و در مواقع ترس و استرس ميزان ترشح

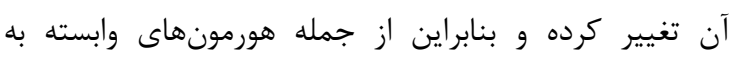
يالسهاى عصبى است. همجنين اين هورمون بر فعاليت بسيارى

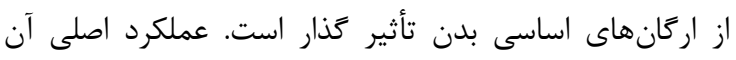

مىباشد كه براساس روش آمارى T-Test و استفاده از برنامه نشان دهنده اختلاف معنادارى براى دو گروه شاهد و وارى

$$
\text { آزمون بود (ه • • • (P) }
$$

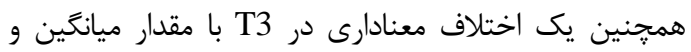

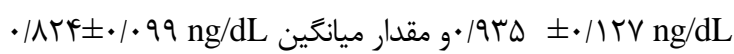
به ترتيب براى كروه آزمون و شاهد با اختلاف معنادارى مشاهده

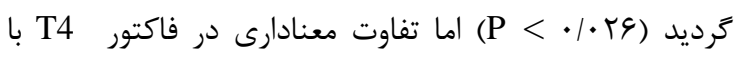

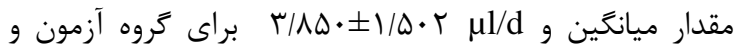
مقدار ميانكين مقدار مينكين و آزمون و شاهد مشاهده نشد (P<اركين (P).

بحث در رابطه با تأثير يا عدم اثرَذارى ميدان هاى

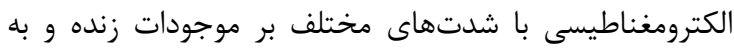

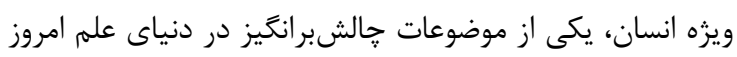


يا اثر بر هييوفيز را علت اصلى افزايش كورتيزول دانسته اند

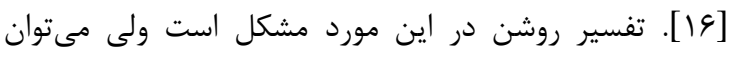
كَفت واكنش به محرك به عوامل بسيار زيادى از جمله

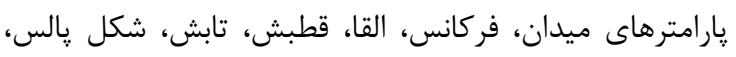

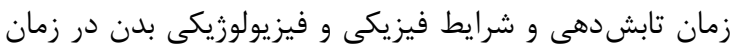

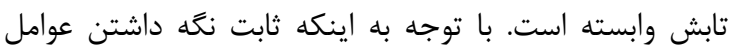
مداخله

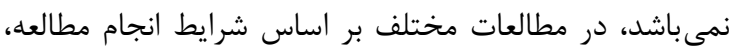

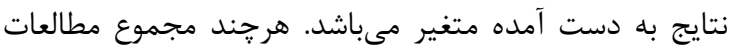

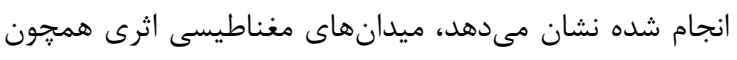

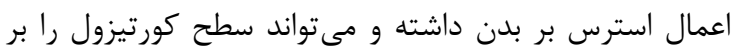

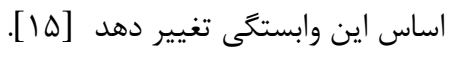

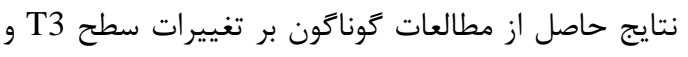

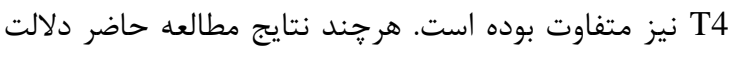

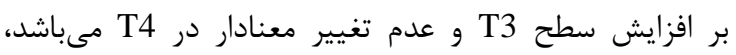

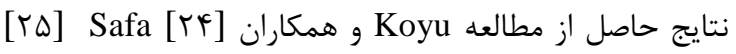

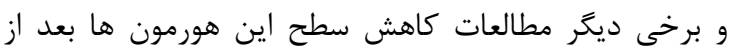

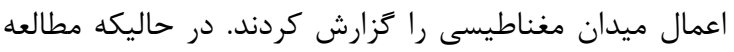
[بr Magin مغناطيسى در سگها را نشان داده است كه با نتايج مطالعه

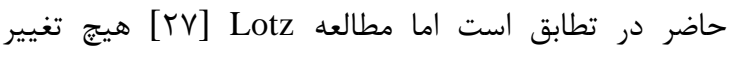
معنادارى در سطح اين هورمون ها ناشى از اعمال ميدان

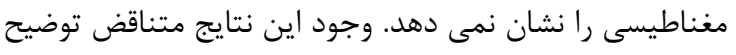

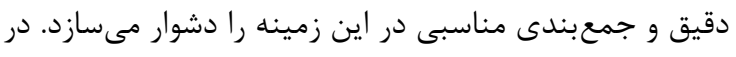

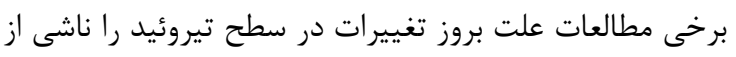
اثر شار مغناطيسى در هييوتالاموس و هيیوفيز دانسته كه

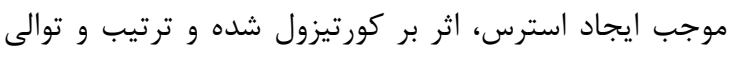

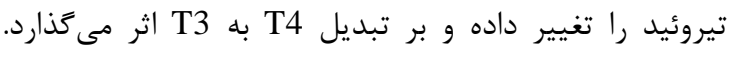

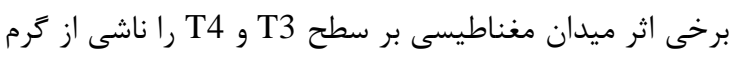

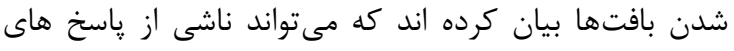

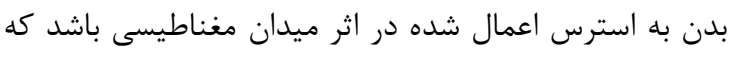

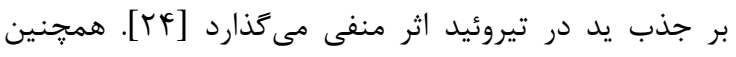

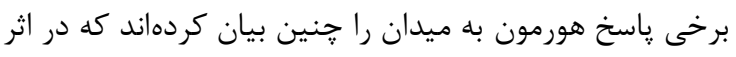

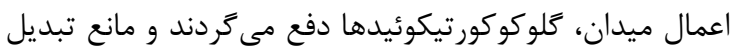

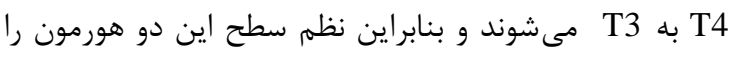
بهم مىزنند. البته عامل مدت زمان تابشدهى دهى نيز فاكتور مؤثر

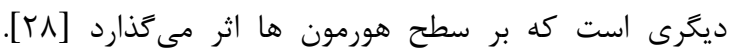

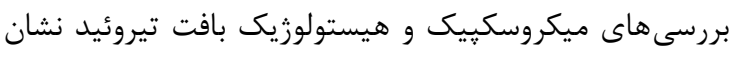

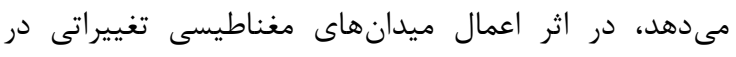

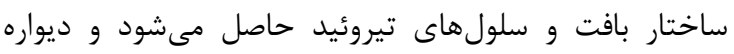
فوليكولها تحريك و در برخى مواقع ديواره برخى گسيخته

مى شود [rq]. هرجند نتايج حاصل از اين مطالعه تأثير معنادارى بر سطح

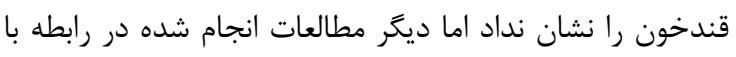

تأثير بر دستخاه زنتيك سلولى بوده و علاوه بر آن نقش مهمى

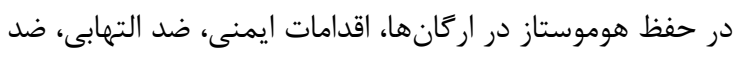
آلرزيك، مهار هورمونهاى استروزن و يروزسترون، عملكرد آب و هوني

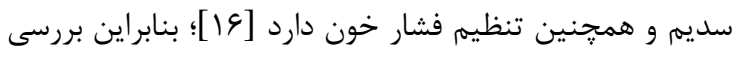

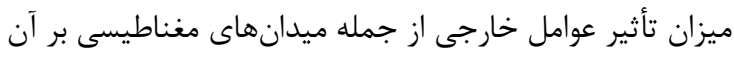

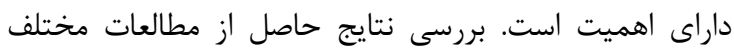

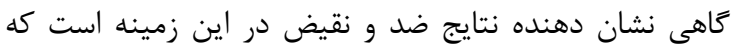

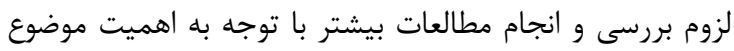
را ضرورى مىسازد. در اين مطالعه ميدان مغناطيسى با شدت مئسرد فر كانس برق شهر بر روى موشهاى صحرايى اعمال كرديد و اثر مئر

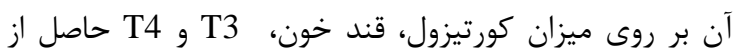

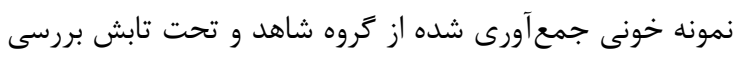

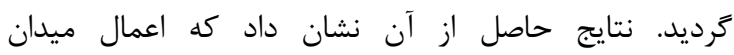

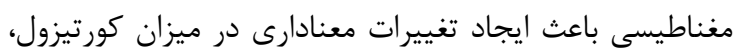

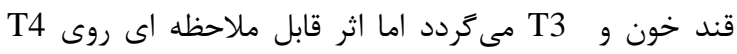

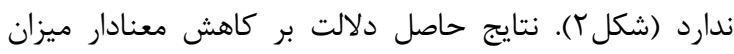

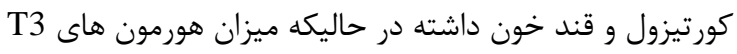

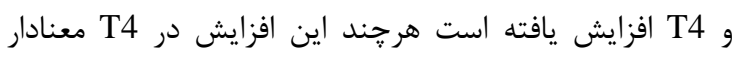
نبوده است. بررسى ساير مطالعات در رابطه با تأثير ميدانهاى

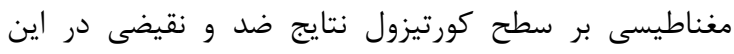

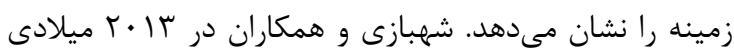
نشان دادند كه ميدان مغناطيسى حاصل از دستخاههاى تصوير

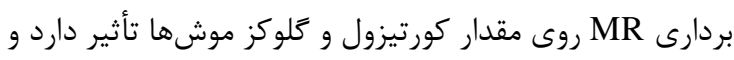

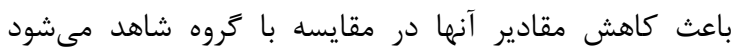

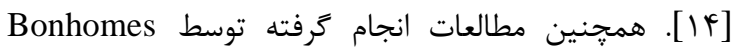

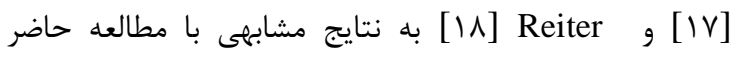
رسيده است؛ در حاليكه مطالعات Hodges-Dawsor

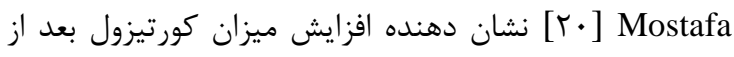
اعمال ميدان مغناطيسى ضعيف است. نتيجه حاصل از مطالعه

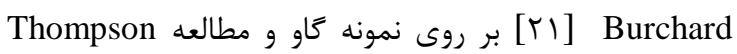
[Tr] بر روى گوسفند هيج تغيير معنادارى بر سطح كورتيزول ندونه

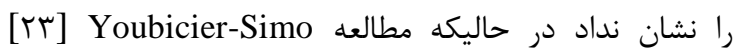

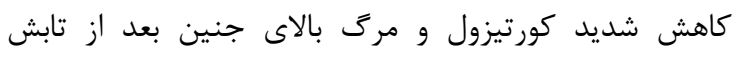

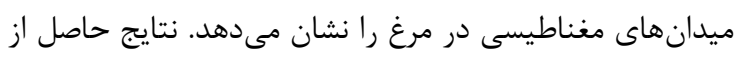

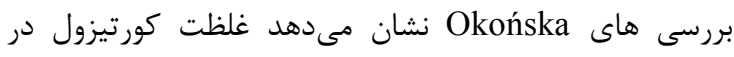

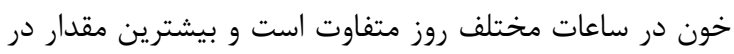

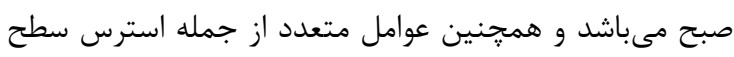

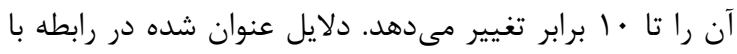

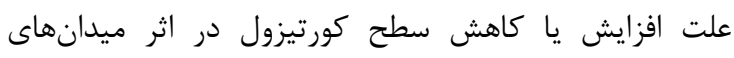
مغناطيسى متفاوت بوده است [19]. برخى مطالعات كاهش كئر

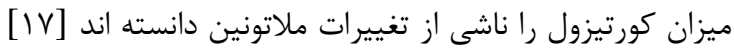

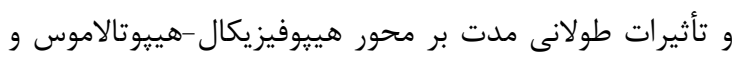




$$
\text { ضرورى به نظر مىرسد. }
$$

با توجه به لزوم بررسىهاى دقيق تر در رابطه با اثرات

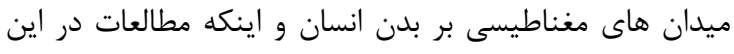

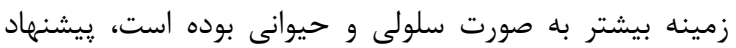

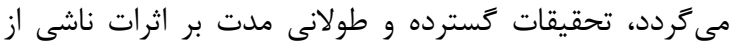

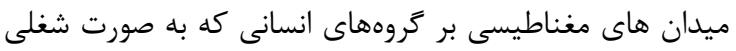

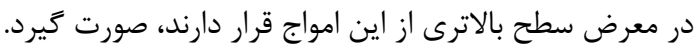

\section{تشعر و قلر داذى}

با تشكر از گروه بيوشيمى دانشخاه علوم يزشكى همدان و و

آزمايشگاههاى تحت نظارت اين كروه كه امكان استفاده از

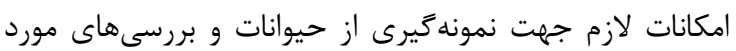
نياز در اين زمينه را فراهم نمودند. با سياس فراوان از آز آزمايشكاه

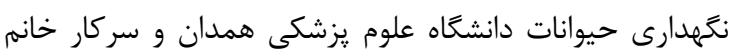

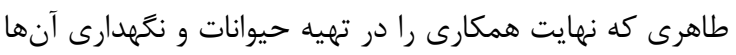

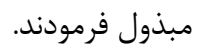

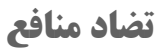
اين مطالعه براى نويسنده هيج كونه تضاد منافعى نداشته

\section{REFERENCES}

1. Myung CG, Chan JP. Effect of electromagnetic field exposure on the reproductive system. Clin Exp Reprod Med 2013; 39 (1): 1-9. doi: 10.5653/cerm.2012.39.1.1. Epub 2012 Mar

2. Goldsworthy A. The biological effects of weak electromagnetic fields. 2007. Available on: www.goldsworthy- bio-weak-em0.7.doc. 1-15.

3. Sieron A, Cieslar G. Application of variable magnetic fields in medicine-15 years' experience. WiadLek 2003; 56: 434441. pmid: 15049208.

4. Hassan BF. Sub chronical effects of electromagnetic field exposure of adult female rats on some hormonal, biochemical and hematological parameters. Diyala Agr Sci J 2011; 3(1): 47-53

5. Volkow ND, Tomasi D, Wang GJ, Fowler JS, Telang F, Wang R, Alexoff D, Logan J. Wong C, Pradhan K, et al. Effects of low-field magnetic stimulation on brain glucose metabolism. Neuroimage 2010; 51: 623-628. pmid: 20156571. pmcid: PMC2862488. doi:10.1016/j. neuroimage.2010.02.015.

6. Hussein AM. Effect of magnetic field on metabolism and enzyme activity on some harmful insects. Minufiya $\mathbf{J}$ of Agric Res 2015; 1:999-1009.

7. Beck BJ, drzejowska SH, Cholewka A, Król W, Drzazga Z. An effect of extremely low frequency magnetic field on immunoglobulin G Concentration in serum. Pol J Envir Stud 2005; 14: 439-445.

8. Koh EK, Ryu BK, Jeong DY, Bang IS, Nam MH. A 60-Hz sinusoidal magnetic field induces apoptosis of prostate cancer cells through reactive oxygen species. Int J Radiat Biol 2008; 84 (11): 945-955. pmid: 19016143. doi: $10.1080 / 09553000802460206$.

9. Nikzad S, Mahmoudi G, Amini P, Baradaran-Ghahfarokhi M, Vahdat-Moaddab A, Sharafi SM, Hojaji-Najafabadi L, Hosseinzadeh A. Effects of radiofrequency radiation in the presence of gold nanoparticles for the treatment of renal cell carcinoma. J Renal Inj Prev 2016; 6(2):103-108. pmid: 28497084. pmcid: PMC5423275. doi: 10.15171/

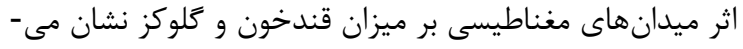

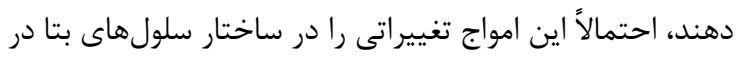
هانكراس ايجاد مىكنند و ميزان سنتز و ترشح انسولين و وهئ

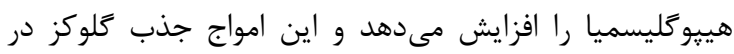

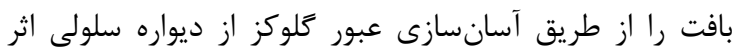

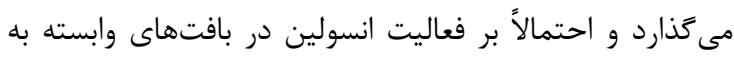

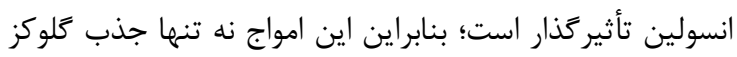

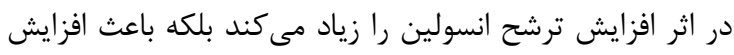

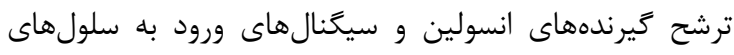

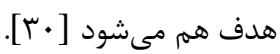

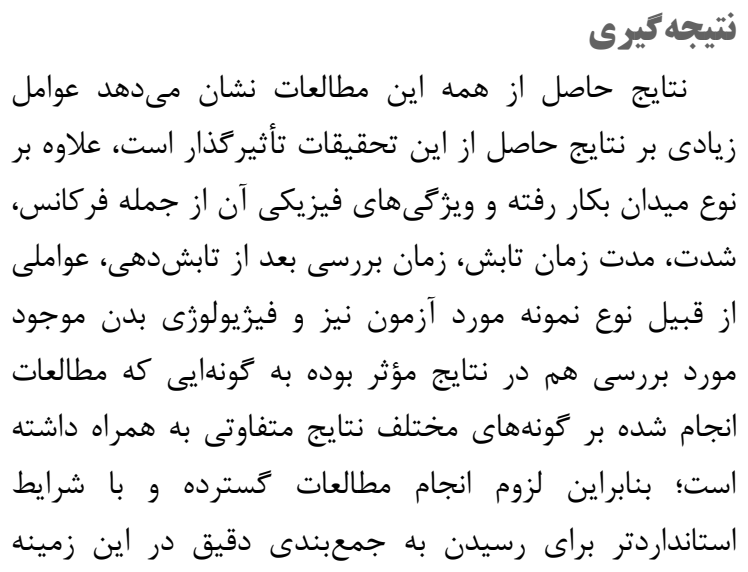
jrip. 2017.20

10. Davis S, Mirick DK, Stevens RG. Residential Magnetic Fields and the Risk of Breast Cancer. Am J Epidemiol 2002; 155:446- 454 . pmid: 11867356

11. Amara S, Abdelmelek H, Salem MB, Abidi R, Sakly M. Effects of Static Magnetic Field Exposure on Hematological and Biochemical Parameters in Rats. Brazilian Archives of Biology and Technology 2006; 49(6): 889-895.

12. Belova NA, Acosta-Avalos D. The Effect of Extremely Low Frequency Alternating Magnetic Field on the Behavior of Animals in the Presence of the Geomagnetic Field. J Biophys 2015. pmid:26823664. pmcid:PMC4707359. doi:10.1155/2015/423838

13. Shabazi Gahrouei D, Koohian F, Koohian M. changes of Cortisol and Glucose concentrations in Rats exposed to MR imaging field, J Biomed Phys Engm 2013;3(1): 9-12.

14. Lewczuk B, Redlarski G, Zak A, Ziółkowska N, Przybylska-Gornowicz B, Krawczuk M. Influence of electric, magnetic,and electromagnetic fields on the circadian system: current stageof knowledge. Biomed Res Int 2014. pmid:25136557. pmcid: PMC4130204. doi: $10.1155 / 2014 / 169459$

15. Woldańska-Okońska M, Czernicki J, Karasek M. The influence of the low-frequency magnetic fields of different parameters on the secretion of cortisol in men. Int J Occup Med Environ Health 2013; 26(1):92-101. pmid:23576151. doi:10.2478/s13382-013-0090-6

16. Bonhomme-Faivre L, Mace A, Bezie Y, Marion S, Bindoula G, Szekely AM, et al. Alterations of biological parameters in mice chronically exposed to low frequency $(50 \mathrm{~Hz})$ electromag-netic fields. Life Sci 1998; 62(14):1271-80. pmid:9570342

17. Reiter RJ. A review of neuroendocrine and neurochemi-cal changes associated with static and extremely low fre-quency electromagnetic field exposure. Integr Physiol Behav Sci 1993; 28(1):57-75. pmid:8476743

18. Hedges-Dawson W, Massari C, Salyer DL, Lund-Trent D, Hellewell JL, Johnson AC, et al. Duration of transcranial 
magnetic stimulation effects on the neuroendocrine stress response and coping behaviour of adult male rats. Prog Neuropsychopharmacol Biol Psychiatry 2003; 27(4):633-8. pmid:12787850.doi:10.1016/S0278-5846(03)00052-6

19. Mostafa RM, Mostafa YM, Ennauceur A. Effects of exposure to extremely low-frequency magnetic field of $2 \mathrm{G}$ intensity on memory and corticosterone in rats. Physiol Behav 2002 ;76(4-5):589-95. pmid:12126997.

20. Burchard JF, Ngujen DH, Richard L, Block E. Biological effects of electric and magnetic fields on productivity of dairy cows. J Dairy Sci 1996; 79(9):1549-54. pmid:8899520. doi:10.3168/jds.S0022-0302(96)76516-5

21. Thompson JM, Stormshak F, Lee JM, Hess DL, Painter L . Cortisol secretion and growth in ewe lambs chronically exposed to electric and magnetic fields of $60 \mathrm{~Hz}, 500-$ kilovolt AC trans-mission line. J Anim Sci 1995; 73(11):3274-80. pmid:8586584

22. Youbicier-Simo BJ, Simo BJ, Boudard F, Cbaner C, Bastide M. Biological effects of continuous exposure of embryos and young chickens to electromagnetic fields emitted by video display units. Bioelectromagnetics 1997; 18(7):514-23. pmid:9338633

23. Koyu A, Cesur G, Ozguner F, Akdogan M, Mollaoglu H, Ozen S. Effects of $900 \mathrm{MHz}$ electromagnetic field on TSH and thyroid hormones in rats. Toxicol Lett 2005 4; 157(3):257-62. pmid:15917150. doi: 10.1016/j.toxlet.
2005.03.006

24. Safaa M, Abo El-Soud, Hussein AM, Rady KE, Allam SA. Magnetic Field Effects on Some Physiological Aspects of Male Albino Rats. Egypt J Chem Environ Health 2016; 2 (2): $211-219$.

25. Magin RL, Lu S, Michaelson SM. Stimulation of dog thyroid by local application of high intensity microwaves. Am J Physiol. 1977; 233(5): 363-8. pmid: 920797. doi:10.1152/ajpendo. 1977.233.5.E363

26. Lotz WG, Podgorski RP. Temperature and adrenocortical responses in rhesus monkeys exposed to microwaves. J Appl Physiol 1982; 53: 1565-1571. pmid: 7153151. doi: 10.1152/jappl.1982.53.6.1565

27. Shayryar HA, Lotfi A, Ghodsi MB, Karami AR. Effects of $900 \mathrm{MHz}$ Electromagnetic fields emitted from a cellular phone on the T3and T4 and Cortisol levels in Syrian Hamsters. Bull vetr Inst Pulawy 2009; 53: 233-236.

28. Dalia AM, Elnegris HM. Histological study of thyroid gland after experimental exposure to low frequency electromagnetic fields in adult male Albino rat and possible protective role of Vitamin E. J Cytol Histol 2015; 6: 374.

29. Sieron A, Konencki J, Ciesar G, Szkilnik R, Nowak P, Norasl L, Kwiecinski A, Kostrazewa RM, Brus R. Effect of low frequency electromagnetic fields on $\left({ }^{3} \mathrm{H}\right)$ Glucos uptake in rat tissues. Polish J of Environ stud 2007; 10(2): 309-312. 